\title{
Cardiovascular Phenotypes and Functional Parameters in the General Population - Results of the MONICA/KORA Studies
}

\author{
H. Schunkert ${ }^{1}$ \\ A. Döring ${ }^{2}$ \\ B. $\mathrm{KuCh}^{3}$ \\ S. Holmer ${ }^{4}$ \\ A. Luchner ${ }^{4}$ \\ M. Muscholl ${ }^{4}$ \\ M. Fischer ${ }^{4}$ \\ C. Hengstenberg ${ }^{4}$ \\ G. A. J. Riegger ${ }^{4}$ \\ H.-W. Hense ${ }^{5}$ \\ for the KORA-Study group
}

\author{
Kardiovaskuläre Phänotypen und Funktionsparameter in der \\ Normalbevölkerung - Ergebnisse der MONICA/KORA-Studien
}

\section{Zusammenfassung}

Die MONICA/KORA-Surveys sind durch eine sorgfältige und breite Erhebung zahlreicher kardiovaskulärer Phänotypen gekennzeichnet. Insbesondere wiederholte, verblindete Blutdruckmessungen, umfassende echokardiographische und elektrokardiographische Ableitungen sowie die Differenzierung zwischen Fett und fettfreier Körpermasse haben zu vielfältigen innovativen Beobachtungen Anlass gegeben. So konnten genetische und serologische Marker des Renin-Angiotensin-Systems mit Bluthochdruck und linksventrikulärer Hypertrophie assoziiert werden. Gleiches gilt für die Bedeutung von Parametern der Körperkomposition, wie Adipositas und Muskelmasse. Zudem konnte erstmalig die Prävalenz der Herzinsuffizienz auf Bevölkerungsebene in Deutschland determiniert werden. Daneben gelangen genaue Prävalenzangaben für die linksventrikuläre systolische bzw. diastolische Dysfunktion in der Studienregion exemplarisch für die Bundesrepublik. Schließlich wurden die Studien in der Bevölkerungsstichprobe für die Definition von Normalwerten der natriuretischen Peptide genutzt. Zusammenfassend betrachtet erlaubte die Evaluation kardiovaskulärer Phänotypen in den MONICA/KORA-Studien eine im europäischen Raum einmalige Dokumentation kardiovaskulärer Funktionsparameter in der Normalbevölkerung. Darüber hinaus gelangen vielfältige epidemiologische Beobachtungen $\mathrm{zu}$ pathophysiologisch relevanten Themen von Herz- und Gefäßerkrankungen.

\begin{abstract}
The MONICA/KORA surveys are characterized by a careful and broad investigation of multiple cardiovascular phenotypes. Particularly, repeated blinded measurements of blood pressure, comprehensive echocardiographic and electrocardiographic evaluations as well as differentiation between fat and fat-free body mass have led to manifold innovative observations. Specifically, genetic and serological markers of the renin angiotensin system could be associated with high blood pressure and left ventricular hypertrophy. The same applies to the importance of parameters of body composition as obesity and muscular mass. Moreover, the prevalence of heart failure in the general population could be determined for the first time in Germany. Additionally, the prevalence of left ventricular systolic and diastolic dysfunction could be obtained in the region of the survey, exemplarily for the Federal Republic of Germany. Finally, the surveys of the population random sample were used to define normal serum levels of natriuretic peptides. In summary, the evaluation of cardiovascular phenotypes in the MONICA/KORA surveys resulted in a - in the European region unique - documentation of cardiovascular functional parameters in the general population. Moreover, multiple epidemiological observations as to pathophysiologically relevant topics of heart and vascular diseases could be studied in extraordinary details.
\end{abstract}

\section{Key words}

Left ventricular hypertrophy $\cdot$ heart failure · genetics · obesity

affiliation

${ }^{1}$ Universitätsklinikum Schleswig-Holstein, Campus Lübeck, Medizinische Klinik II, Lübeck

${ }^{2}$ GSF-Forschungszentrum für Umwelt und Gesundheit, Institut für Epidemiologie, Neuherberg

${ }^{3}$ Klinikum Augsburg, I. Medizinische Klinik, Augsburg

${ }^{4}$ Klinikum der Universität Regensburg, Klinik und Poliklinik für Innere Medizin II, Regensburg

${ }^{5}$ Universität Münster, Institut für Epidemiologie und Sozialmedizin, Münster

correspondence

Prof. Dr. H. Schunkert · Universitätsklinikum Schleswig-Holstein, Campus Lübeck, Medizinische Klinik II . Ratzeburger Allee $160 \cdot 23538$ Lübeck, Germany

bibliography

Gesundheitswesen 2005; 67 Sonderheft 1: S74-S78 @ Georg Thieme Verlag KG Stuttgart • New York DOI $10.1055 / \mathrm{s}-2005-858247$

ISSN 0949-7013 


\section{Schlüsselwörter}

Linksventrikuläre Hypertrophie · Herzinsuffizienz · Genetik · Adipositas

\section{Introduction}

Given the increasing prevalence of multiple risk factors in our societies, cardiovascular diseases play a growing sociomedical role. Moreover, based on precise measurement of arterial blood pressure as well as of other traditional risk factors the pathophysiological understanding of coronary heart disease and heart failure is rapidly growing. The sequential MONICA/KORA surveys became focus of these increasing scientific and methodical possibilities. On the one hand, improved echocardiographical evaluations of left ventricular geometry and function allowed a detailed documentation of cardiac function. Additionally, the MONICA/KORA surveys were accompanied by steadily improved genetic technologies. Thereby, correlations between multiple anthropometric factors with pathological changes of heart volume and function as well as the evaluation of genetic polymorphisms or mutations yielded a plethora of novel insights. The present paper sums up the essential results of these works.

\section{Methods}

Electro- and echocardiographic examination form the core methods in this part of the MONICA/KORA surveys. About 2,200 standard examinations have been carried out on subjects of a follow-up of the first survey in 1984/85 (S1) in 1994 as well as large parts of the third survey in 1994/95 (S3). The number of participants in these echocardiographic sub-studies was lower than in the overall survey, due to restriction to the Augsburg city recruitement center. The studies made use of data from the first MONICA survey that allowed comparative analyses in terms of blood pressure and ECG data. Technically, the protocols were carried out in a standardized fashion by specially trained personnel. Particularly, great care was used in order to generate high quality echocardiographic readings. For this purpose, two highly experienced investigators underwent specific training to produce consistent results. The same applies for electrocardiographic readings that were digitized for further analyses. Blood was subsequently taken for generation of serum, plasma and DNA samples. Biochemical and molecular genetic methods have been described elsewhere in great detail.

\section{Results}

\section{Left ventricular hypertrophy Renin angiotensin system}

Starting point for the epidemiological studies were experimental data of our group that demonstrated the involvement of angiotensin converting enzyme (ACE) in the development of pressure induced left ventricular hypertrophy $[1,2]$. Interestingly, data on a polymorphism that results in elevated ACE levels corroborated these findings and demonstrated that this genetically driven induction of the renin angiotensin system elevates the risk of left ventricular hypertrophy [3]. Subsequently, our group demon- strated that an ACE insertion/deletion (I/D) polymorphism specifically elevates ACE activity in the heart [4]. Likewise, other components of the renin angiotensin system were associated with cardiac mass $[5,6]$. In conjunction, experimental and epidemiological data further strengthened the pathophysiological role of an activated renin angiotensin system in the development of left ventricular hypertrophy [7]. Not surprisingly, recent clinical studies using blockers of the renin angiotensin system came to the conclusion that inhibition of this system is specifically useful for reversal of these effects [8].

\section{Blood pressure}

Pressure overload, i. e. a continuously higher systolic pressure in the heart giving rise to an increased wall tension, is traditionally seen as a major contributor to the development of left ventricular hypertrophy. The same was true in the MONICA/KORA studies, although the intensive cardiovascular phenotyping produced a number of additional modifying factors. One of these was the so-called white coat effect, i. e. the surge of blood pressure upon contact with a physician. This slightly stressful encounter was also observed in some study participants who displayed higher blood pressure readings when measurements were taken by the physician as compared to the technician. Interestingly, the white coat effect was also found to increase the probability of left ventricular hypertrophy [9]. Moreover, obesity and obesity related hypertension were found to come with substantial implications for left ventricular geometry. While hypertension was particularly correlated with a concentric type of hypertrophy, obesity was found to induce an excentric pattern. The combination of both, hypertension and obesity, came with the strongest effects [10-13] increasing both geometric forms of left ventricular hypertrophy.

\section{Indexation}

Detailed measurements of fat and fat-free mass allowed further novel investigations with respect to implications of body composition and left ventricular geometry [14]. First, these studies clearly demonstrated that left ventricular mass is best correlated with fat-free mass, i. e. the type of tissue that deserves most of the blood supply [15]. By contrast, fat mass was associated with the risk of hypertension and, thus, a concentric pattern cardiac hypertrophy. Interestingly, the indexation of left ventricular mass for fat-free mass of a given individual diminished the association between fat mass and left ventricular mass. This surprising effect may be explained by higher fat-free mass as a result of obesity in addition to the expected increase of fat mass. Indexation for this increase of fat-free mass reduces the association of fat mass or obesity with left ventricular mass considerably. Moreover, this type of indexation (LVM divided by fat-free mass) completely abolished the differences in cardiac size traditionally observed between men and women. In fact, indexation of fat-free mass was the first ever observed indexation that produced identical (adjusted) heart sizes for men and women [15].

\section{Hypertension}

A number of neurohormones were also associated with blood pressure in the MONICA/KORA samples. In addition to components of the renin angiotensin system [16] dehydroepiandosterone was found to correlate with blood pressure [17]. This effect was particularly interesting, because substitution of this hor- 


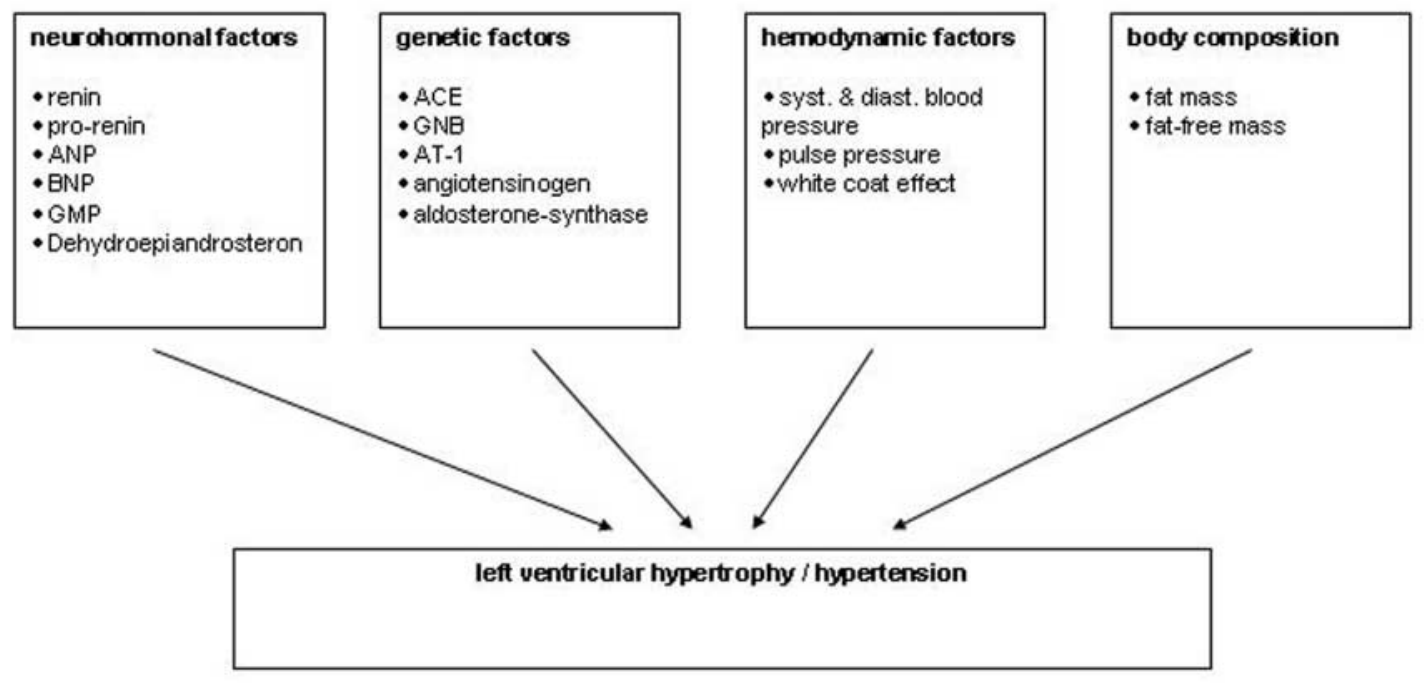

Fig. 1 Factors studied in the Augsburg MONICA/KORA population affecting left ventricular hypertrophy.

mone is considered to delay aging in men resulting in enormous over the counter prescriptions in the United States.

\section{Natriuretic peptides}

Another class of hormones related to cardiac function are the natriuretic peptides. Measurements of arterial natriuretic peptides (ANP), brain natriuretic peptides (BNP) and their second messengers CGMP were also correlated with left ventricular mass and function as well as renal function in the MONICA/KORA surveys $[18-20]$. The data served to create population-based reference levels given that these markers proved to be useful for clinical diagnosis of heart failure, cardiac hypertrophy and aortic stenosis and, finally, may prove useful for making treatment decisions.

\section{Medication}

In addition to anthropometric, genetic and biochemical promotors, medication was investigated with respect to its consequences on blood pressure, hypertrophy and neurohormone levels [21-26]. Interestingly, these studies produced highly differential results with respect to drugs affecting the renin angiotensin system or sympathetic nervous system, respectively. Specifically, diuretics, ACE inhibitors or the combination of both resulted in a stepwise increase of renin levels, whereas beta blockers, either alone or in combination with such drugs, almost abolished this effect. By contrast, beta blockers were related to an increase of ANP, BNP and cyclic GMP levels. These data were of great interest given the pathophysiological implications of an activation of the renin angiotensin system [ $1-5]$ or the diagnostic value of the natriuretic peptides [18].

\section{Genetic factors}

In parallel with the evolution of the human genome project, the MONICA/KORA studies produced a large wealth of data on genetic factors with respect to their implications for arterial hypertension and left ventricular hypertrophy [3, 27-35]. In addition to the ACE I/D polymorphism, other genetic variants of the renin angiotensin system including angiotensinogen, AT1 receptor, aldosterone synthase, PPAR $\alpha$ and GNB3 polymorphisms were studied in great detail. In conjunction, these studies document both

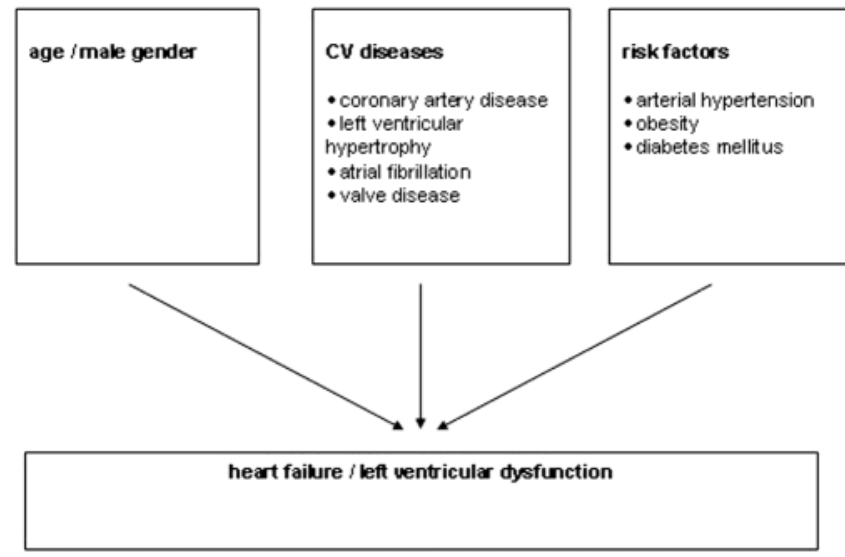

Fig. 2 Factors studied in the Augsburg MONICA/KORA population affecting cardiac function.

the profound implication of inherited factors in general [36] and those of the renin angiotensin system in particular.

\section{Cardiac function}

The systematic exploration of more than 2,000 inhabitants of the Augsburg region allowed for the first time to produce population-based data on systolic and diastolic function of the heart [37-39]. In the context of other echocardiographic investigations of MONICA populations including Glasgow and others, these data were important for the definition of screening strategies for these dreadful conditions. In detail, these studies revealed that men are more likely to suffer from both systolic and diastolic dysfunction of the heart. Moreover, blood pressure, obesity and anemia proved to affect cardiac function substantially [37-41].

\section{Discussion}

The close interaction between cardiologists and epidemiologists in the MONICA/KORA surveys proved to be highly fruitful for the elaboration of cardiac geometry and function. Indeed, this interdisciplinary interaction allowed for the first time to generate an 
extensive German database on cardiac function and geometry as well as their related factors. The wide scope of these investigations and the enormous success in terms of high impact publications certainly enhanced the visibility of the Augsburg MONICA/ KORA studies substantially. Indeed, some of the landmark studies on epidemiological aspects of left ventricular hypertrophy, heart failure and contributing factors such as the ACE I/D polymorphism were derived from the MONICA/KORA studies that introduced novel concepts to be reproduced in many other studies $[3,15,37]$. The follow-up of these investigations kicked off numerous successful grant applications including the BMBF Kompetenznetz Herzinsuffizienz and NGFN2.

\section{Future planning}

In the currently ongoing study the population-based follow-up of the third survey from 1994/95 (S3) in 2004/05 (F3) allows to investigate for the second time a population-based sample by electro- and echocardiography as well as measurement of body impedance. These consecutive measurements covering a period of 10 years will form a unique database for the investigation of factors affecting the incidence of hypertension, left ventricular hypertrophy and heart failure. Thus, the ongoing evaluations are likely to contribute to these topics under investigations for many years to come.

\section{Acknowledgement}

The investigations have been supported by GSF and grants from BMBF - Federal Ministry of Education and Research (KBF 01 GB 9493, 01GI0205, 01GS0499) and DFG - Deutsche Forschungsgemeinschaft (Schu 672/9-1, Schu 672/10-1, Schu 672/12-1).

\section{References}

${ }^{1}$ Schunkert $\mathrm{H}$, Ingelfinger JR, Hirsch AT et al. Evidence for tissue specific activation of renal angiotensinogen mRNA expression in chronic stable experimental heart failure. J Clin Invest 1992; 90: 1523 - 1529

2 Schunkert H, Jackson B, Tang SS et al. Distribution and functional significance of cardiac angiotensin converting enzyme in hypertrophied rat hearts. Circulation 1993; 87: 1328 - 1339

${ }^{3}$ Schunkert H, Hense HW, Holmer SR et al. Association between a deletion polymorphism of the angiotensin-converting-enzyme gene and left ventricular hypertrophy. New Engl J Med 1994; 330: 1634-1638

${ }^{4}$ Danser AH, Schalekamp MA, Bax WA et al. Angiotensin-converting enzyme in the human heart. Effect of the deletion/insertion polymorphism. Circulation 1995; 92 (6): 1387-1388

${ }^{5}$ Muscholl MW, Schunkert H, Muders F et al. Neurohormonal activity and left ventricular geometry in patients with essential arterial hypertension. Am Heart J 1998; 135: 58 - 66

${ }^{6}$ Schunkert H, Hense HW, Muscholl M et al. Associations between circulating components of the renin-angiotensin-aldosterone system and left ventricular mass. Heart 1997; 77: $24-31$

${ }^{7}$ Schunkert H, Hense HW. Molekulare Genetik kardiovaskulärer Erkrankungen. Dtsch med Wschr 1995; 120: 533-539

${ }^{8}$ Lindholm LH, Ibsen H, Dahlof B et al. Cardiovascular morbidity and mortality in patients with diabetes in the Losartan Intervention For Endpoint reduction in hypertension study (LIFE): a randomised trial against atenolol. Lancet 2002; 359 (9311): 1004-1010

${ }^{9}$ Muscholl MW, Hense HW, Brockel U et al. Changes in left ventricular structure and function in patients with white coat hypertension: cross sectional survey. BMJ 1998; 317: 565-570

${ }^{10}$ Kuch B, Muscholl M, Luchner A et al. Geschlechtsunterschiede in der Beziehung zwischen Übergewicht und Hypertonie mit linksventrikulärer Masse und Hypertrophie. Z Kardiol 1996; 85: 334 - 342

${ }^{11}$ Hense HW, Gneiting B, Muscholl M et al. The associations of body size and body composition with left ventricular mass: impact for indexation in adults. J Am Coll Cardiol 1998; 32: 451 - 457

${ }^{12}$ Kuch B, Hense HW, Gneiting B et al. Body composition and prevalence of left ventricular hypertrophy. Circulation 2000; 102: 405-410

${ }^{13}$ Kuch B, Gneiting B, Döring A et al. Indexation of left ventricular mass in adults with a novel approximation for fat free mass. J Hypertens 2001; 19: 135 - 142

${ }^{14}$ Kuch B, Muscholl M, Luchner A et al. Gender specific differences in left ventricular adaptation to obesity and hypertension. J Hum Hypertens 1998; 12: 685-691

${ }^{15}$ Hense HW, Schunkert H. Relations of left ventricular mass to fat-free and adipose body mass. Circulation 1999; 100: e145 [electronic pages]

${ }^{16}$ Schunkert H, Hense HW, Muscholl M et al. Association of angiotensin converting enzyme activity and arterial blood pressure in a population-based sample. J Hypertens 1996; 14: 571 - 575

17 Schunkert H, Hense HW, Andus T et al. Relation between dehydroepiandrosterone sulfate and blood pressure levels in a populationbased sample. Am J Hypertens 1999; 12 (11 Pt 1): 1140-1143

${ }^{18}$ Luchner A, Burnett JC Jr, Jougasaki M et al. Evaluation of brain natriuretic peptide as marker of left ventricular dysfunction and hypertrophy in the population. J Hypertens 2000; 18: 1121 - 1128

${ }^{19}$ Luchner A, Brockel U, Muscholl M et al. Gender-specific differences of cardiac remodeling in subjects with left ventricular dysfunction: a population-based study. Cardiovasc Res 2002; 53: 720-727

20 Luchner A, Hengstenberg C, Lowel $\mathrm{H}$ et al. N-terminal pro-brain natriuretic peptide after myocardial infarction: a marker of cardio-renal function. Hypertension 2002; 39 (1): 99- 104

${ }^{21}$ Schunkert H, Danser AH, Hense HW et al. Effects of estrogen replacement therapy on the renin angiotensin system in postmenopausal women. Circulation 1997; 95: 39-45

${ }^{22}$ Frohlich M, Schunkert H, Hense HW et al. Effects of hormone replacement therapies on fibrinogen and plasma viscosity in postmenopausal women. Br J Haematol 1998; 100: 577-581

${ }^{23}$ Holmer SR, Hense HW, Danser AH et al. Beta-adrenergic blockers lower renin in patients treated with ACE inhibitors and diuretics. Heart 1998; 80: $45-48$

${ }^{24}$ Luchner A, Burnett JC Jr, Jougasaki M et al. Augmentation of the cardiac natriuretic peptides by beta-receptor antagonism: evidence from a population-based study. J Am Coll Cardiol 1998; 32: 1839-1844

25 Schunkert H, Hense HW, Brockel U et al. Differential effects of antihypertensive drugs on neurohormonal activation: insights from a population-based sample. J Int Med 1998; 244: 109-119

${ }^{26}$ Straub RH, Hense HW, Andus T et al. Hormone replacement therapy and interrelation between serum interleukin 6 and body mass index in postmenopausal women: a population-based study. J Clin Endocrinol Metab 2000; 85: $1340-1344$

${ }^{27}$ Schunkert H, Hense HW, Gimenez-Roqueplo AP et al. The angiotensinogen T235 variant and the use of antihypertensive drugs in a population-based cohort. Hypertension 1997; 29: 628-633

${ }^{28}$ Hengstenberg C, Schunkert H, Mayer B et al. Association between a polymorphism in the G protein beta3 subunit gene (GNB3) with arterial hypertension but not with myocardial infarction. Cardiovasc Res 2001; 49: $820-827$

${ }^{29}$ Jamshidi Y, Montgomery HE, Hense HW et al. Peroxisome proliferator - activated receptor alpha gene regulates left ventricular growth in response to exercise and hypertension. Circulation 2002; 105: 950-955

${ }^{30}$ Schunkert H, Hense HW, Döring A et al. Association between a polymorphism in the $G$ protein beta3 subunit gene and lower renin and elevated diastolic blood pressure levels. Hypertension 1998; 32: 510-513

${ }^{31}$ Danser AH, Derkx FH, Hense HW et al. Angiotensinogen (M235T) and angiotensinogen-converting enzyme (I/D) polymorphisms in association with plasma renin and prorenin levels. J Hypertens 1998; 16: $1879-1883$

32 Schunkert H, Hengstenberg C, Holmer SR et al. Lack of association between a polymorphism of the aldosterone synthase gene and left ventricular structure. Circulation 1999; 99: 2255-2260

${ }^{33}$ Hengstenberg C, Holmer SR, Mayer B et al. Evaluation of the aldosterone synthase (CYP11B2) gene polymorphism in patients with myocardial infarction. Hypertension 2000; 35: 704-709 
${ }^{34}$ Zhang X, Erdmann J, Regitz-Zagrosek V et al. Evaluation of three polymorphisms in the promoter region of the angiotensin II type I receptor gene. J Hypertens 2000; 18: 267-272

35 Sedlacek K, Fischer M, Erdmann J et al. Relation of the G protein beta3subunit polymorphism with left ventricle structure and function. Hypertension 2002; 40: $162-167$

${ }^{36}$ Schunkert H, Brockel U, Hengstenberg C et al. Familial predisposition of left ventricular hypertrophy. J Am Coll Cardiol 1999; 33: 1685-1691

37 Schunkert H, Broeckel U, Hense HW et al. Left-ventricular dysfunction. Lancet 1998; 351: 372 [letter]

${ }^{38}$ Fischer M, Baessler A, Holmer SR et al. Epidemiology of left ventricular systolic dysfunction in the general population of Germany: results of an echocardiographic study of a large population-based sample. Z Kardiol 2003; 92: 294-302 